\title{
Genetic Diversity of Plain Medium Resistant of Chrysanthemum Planlet Produced of Gamma Ray Irradiation
}

\author{
Ari Wijayani*, Rina Srilestari \\ Department of Agrotechnology, Faculty of Agriculture, UPN “Veteran” Yogyakarta, Indonesia. \\ * Corresponding author. Tel.: +8562900200; e-mail: ariewijayani@yahoo.com \\ Manuscript submitted June 30, 2016; accepted August 19, 2016. \\ doi: 10.17706/ijbbb.2016.6.4.139-144
}

\begin{abstract}
Genetic diversity can be improved using the gamma ray irradiation to obtain the resistant plants to the disease. The Changes occur can be analyzed at the beginning of plant growth using molecular analysis; RAPD technique (Random Amplified Polymorfism DNA). This study aims to determine the genetic diversity produced by gamma rays irradiated and given the poly ethilene glycol given in plantlets to increase chrysanthemum resistance to Medium plain. The study used four primers tested on four treatments that were not irradiated plantlets and induced the poly ethilene glycol, gamma rays irradiated 25 gray un induced poly ethilene glycol, irradiated and induced the poly ethilene glycol 15 and 30\%.The results showed a decrease of control diversity of genetic 0.20 to 0.30 in 25 gray irradiation treatment with given the poly ethilene glycol 15\%.The use of the RAPD technique to determine genetic diversity resulting from gamma ray irradiation on the level of plantlets. Gamma ray irradiation treatment causing mutations in all treatments tested. Plantlets of 25 gray irradiation induced with 15\%poly ethylene glycol / l showed changes in DNA structure.
\end{abstract}

Key words: Chrysanthemum, irradiation, polyethylene-glycol.

\section{Introduction}

Chrysanthemums come from subtropical countries will grow best when planted in areas that have a height of $900 \mathrm{~m}$ above sea level. The quality of chrysanthemum flowers will decrease if the plant cultivated in the plains of medium to low [1], [2]. Observations in Hargobinangun which have a height of $700 \mathrm{~m}$ showed that the condition of crops is not fertile, mostly plant disease (rust, fusarium wilt, etc.), flowers are small and the color is no longer as bright as the original. We suspect the decline in quality of plant growth due to genetically engineered crops has changed. It happened because the farmers use seeds from the low quality of parent tree or even replant the same crop repeatedly. In addition, the seed that had been planted by farmers is specific to the highlands (above $900 \mathrm{~m}$ above sea level), so when It is planted in plain medium (700 $\mathrm{m}$ asl) will tend to degrade [3], [4]. Flowers are dull, pale and faded other than that.

PEG (Polyethylene Glycol) can be used to obtain the resistant plants to drought and high temperatures, in the field or in tissue culture. Research conducted by [5] has succeeded in doing the selection of upland rice using PEG 15\%. PEG is a solution of high temperature stress simulation considering taking water or imbibition will be disrupted, resulting in stunted germination [6]-[8]. PEG containing two cell adhesion activity and other properties may interfere with or disrupt the phospholipid bilayer of the membrane layer 
that is holding the adhesion, then it's reorganized until the perfect fusion occurs. Here the activity of PEG is as an intermediary molecule in enhancing the activity of two kinds of plasmolemma or protoplasts. The use of PEG needs special attention because these compounds can act as sito-toxicity to the cells of the plant [5], [9], [10].

\section{Methodology}

The study was conducted in the net work culture laboratory of the Faculty of Agriculture UPN "Veteran" Yogyakarta in two stages. Phase I 25 gray gamma ray Irradiation. While phase II is the chrysanthemum tolerance test against PEG (Polyethylene Glycol). In the tolerance test of chrysanthemum against PEG performed on plantlets growth was good after gamma irradiation, which is still green, then moved into the test medium. Research using laboratory experiments completely randomized design (CRD) of the factors that PEG formulations, namely: $0 \%$ is equivalent to an osmotic potential of $0 \mathrm{MPa}, 15 \%$ is equivalent to an osmotic potential -2.01 MPa and 30\%, or -4 osmotic potential, $02 \mathrm{Mpa}$. Of these factors is repeated 6 times with each treatment consisting of 10 bottles, and each bottle contains 2 explants.

Implementation study begins by planting the plantlets results of phase I study further grown in medium supplemented with appropriate PEG treatment. Four weeks after the subculture plantlets will show different conditions, resistant plantlets will remain green while the plantlets that cannot stand black and die. Criteria resistant plantlets is if more than $1 / 2$ part of plantlets were treated live or embryonic. Explants were put into culture bottles and then sealed with aluminum foil and then stored in room temperature incubation $24^{\circ} \mathrm{C}$. With irradiation intensity of 16 hours per day. Maintenance is done until the plants are 8 weeks old. DNA analysis is done to look for resistance to high temperatures with RAPD.

\section{Results and Discussion}

\subsection{Tolerance Test with PEG}

During the incubation period since the explants planted until the end of the study observed various changes in the explant. These changes include the presence of several explants that are not growing, the emergence of buds on explants were planted as well as the change in color and shape of the explants. Initial response that occurs in most of the explants after planting is the swelling of tissue explants. According [1], changes in the explant is linked to the level of osmolarity of the media used. [4] states that the swelling of the tissue due to the influence of nutrients and the addition of growth regulators.

Table 1. Effect of PEG on the Percentage of Life and Conditions of the Plantlets Treatment Percentage of Life

\begin{tabular}{cccc}
\hline Treatment & $\begin{array}{c}\text { Life procentage } \\
(\%)\end{array}$ & Diameter callus $(\mathrm{cm})$ & $\begin{array}{c}\text { Conditions of the } \\
\text { plantlets }\end{array}$ \\
\hline PEG 0\% & 75.00 & 0.5 & Fresh Green \\
\hline PEG 15\% & 50.23 & 2.33 & Light Green \\
\hline PEG 30\% & 49.98 & 1.00 & Pale Green \\
\hline
\end{tabular}

In Table 1 we can see that in the media with PEG $0 \%, 15 \%$ and $30 \%$ indicates the percentage grew by $75 \%, 50.23 \%$ and $49.98 \%$. it is Showed that plants at a concentration of PEG $15-30 \%$ still survive in the sense tolerant to high temperatures. Ref. [5], [11] suggest that the lack of water will suppress the vegetative growth of the plants, as reflected in smaller leaves, reduced stem diameter and plant dry weight. And is also seen from the decline in the rate of plant growth and relative growth rate as a result of decreased efficiency of photosynthesis is visible from the reduction in net assimilation rate. The increase of the running photosynthesis to reduce crop yield components and both quality and quantity. Ref. [5] examined the rice plants through tissue culture in MS medium added PEG - 6000 with a combination of $0-20 \%$ in a study 
stating that the $0 \%$ PEG equivalent to the potential osmotic $0 \mathrm{MPa}, 10 \%$ is equivalent to -, $43 \mathrm{MPa}$ and $20 \%$ equivalent to $-0.81 \mathrm{Mpa}$. The plant showed that the concentration of PEG $20 \%$ still survive within the meaning of drought tolerant.

The growth shown by the increment size cannot be returned. The growth reflects increased plant size protoplasm that occur both cell size and in the number of cells. Plant growth is supported by the availability of water, nutrients in the growth medium [1], [12]. The Water availability will lead to slow growth plantlets. Drought stress also affects the growth and yield, the magnitude of the effect depends on the degree of dryness and the growth phase when the water shortage.

Plant resistance to water shortage between species and varieties with the most susceptible to the level of the most resistant. The response of plants to the environment, usually due to changes in metabolism. If the changes are severe enough to be cause tissue damage, and even death. The limits of endurance caused by atrophy and tissue death, loss of turgor, the leaves fall until the plant dies. In drought stress plants adapt to survive to become plants that are tolerant to drought, while drought tolerance [1]: growth will be dominated in the stem and leaf growth, leaf area will be smaller mean number of stomata will be little, evaporation will run slower, increase in ABA at the plant will increase / lotespecially on the leaves, the amount of grain in panicle less, the plant roots will penetrate the ground deeper, to find more water.

The use of PEG 6000 on the cultivation of the cells may help cells to better withstand $\mathrm{NaCl}$ compared with cells that are not selected. Ref. [5] stated PEG 6000 can help stress in the cell cultivation medium, so that the cells are resistant in this medium will be resistant to stress. Stress to temperature changes which cannot change the contents of cell fluid. Plantlets growth inhibited at each concentration showed the growth inhibition. This is due to disruption of metabolic mechanisms and binding of water molecules by plant roots [6], [11]. [12] examined the cells cultured tomatoes in medium MS added PEG 6000 to $20 \%$ were eventually obtained crops that are resistant to drought stress.

\subsection{The Observations of Molecular}

Genetic diversity can be observed morphologically and molecularly. This occurs because of changes in the segment or segments of their inserts on other chromosomes cannot be observed with the use of microscopes. The genetic diversity caused by a mutation can be detected at a molecular level by using the technique of DNA fingerprinting existence of bands ofDNA amplification with all primary likely due to their complementary sequences on the DNA strand or contained (strand) containing sequences complementary to the primer.

Table 2. Primary (Production Operon Technologies) Were Used to Screen for Resistance to the High Temperatures with Impact of

\begin{tabular}{lll}
\hline NO & Primer & sequences (5 '-3') \\
\hline 1 & OPA 1 & CAGGCCCTTC \\
\hline 2 & OPA 2 & TGCCGAGCTG \\
\hline 3 & OPA 19 & CAAACGTCGG \\
\hline 4 & OPA 20 & GTTGCGATCC \\
\hline
\end{tabular}

Annealing and amplification of a DNA loci due to complementary base pairing nukleitida primers used in the DNA strand. Appears least a locus on a sample of the plant can be caused by differences in the composition of nukleitida bases in DNA samples so that the same primer cannot be attached and therefore cannot amplify loci. This difference is known as polymorphism. With RAPD technique can be seen polymorphism found in chrysanthemum plants which are not irradiated as a positive control (F0) with chrysanthemum irradiated gamma rays 25 gray (F1) and irradiated in the impact of PEG 15\% (F2) and PEG 30\% (F3) is shown in Fig. 1. 


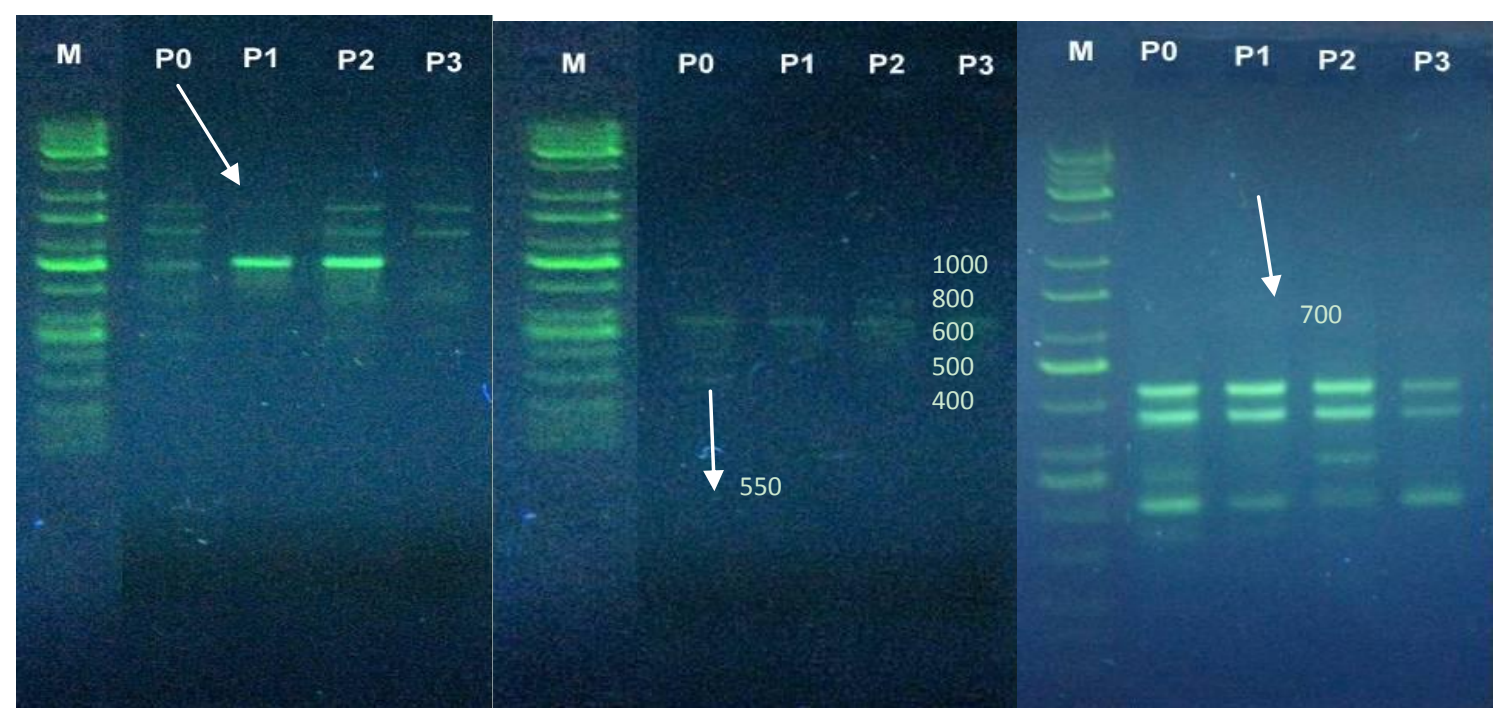

Fig. 1. Results of the callus amplification chrysanthemum irradiated with 25 gray impact of PEG at different doses.

The arrow indicates the addition and subtraction tape that does not exist in another population

Analysis of genetic diversity based on Nei's gene diversity GenAlEx6.1 is done with the program shown in Table 3. Diversity is calculated based on allele frequencies ( 1 and 0 ) and the number of polymorphic loci, which shows genetic diversity in populations of plants irradiated with Co-60 gamma rays. This causes coefficient value diversity in line with the value of the percentage of polymorphic loci, e.g the higher the percentage of polymorphic loci were higher coefficient of diversity that arise. Polymorphisms that occur from RAPD analysis shown with the formation of the DNA bands in the individual one while the other individual is not formed in ribbon on the position or the same size. With the primary polymorphism will show the level of genetic diversity. In all primers tested DNA bands were formed between 100 to $1200 \mathrm{bp}$.

Table 3. The Genetic Diversity Caused by Gamma Ray Irradiation 25 Gray and PEG Impact

\begin{tabular}{|c|c|c|c|c|c|c|c|c|}
\hline Pop & & $\mathrm{N}$ & $\mathrm{Na}$ & $\mathrm{Ne}$ & $\mathrm{I}$ & $\mathrm{h}$ & uh & \%polimorfism \\
\hline F0 & Mean & 3.000 & 1.280 & 1.416 & 0.331 & 0.231 & 0.347 & $52.00 \%$ \\
\hline & $\mathrm{SE}$ & 0.000 & 0.169 & 0.082 & 0.065 & 0.045 & 0.068 & \\
\hline F1 & Mean & 3.000 & 1.080 & 1.256 & 0.204 & 0.142 & 0.213 & $32.00 \%$ \\
\hline & SE & 0.000 & 0.152 & 0.076 & 0.061 & 0.042 & 0.063 & \\
\hline F2 & Mean & 3.000 & 1.200 & 1.320 & 0.255 & 0.178 & 0.267 & $40.00 \%$ \\
\hline & SE & 0.000 & 0.153 & 0.080 & 0.064 & 0.044 & 0.067 & 0.187 \\
\hline F3 & Mean & 3.000 & 0.960 & 1.224 & 0.178 & 0.124 & $28.00 \%$ \\
\hline Total & SE & 0.000 & 0.158 & 0.073 & 0.058 & 0.041 & 0.061 & \\
\hline & Mean & 3.000 & 1.130 & 1.304 & 0.242 & 0.169 & 0.253 & $38.00 \%$ \\
\hline
\end{tabular}

Remark $: \mathrm{N}=$ Number of alel; $\mathrm{Na}=$ Number of different alel, $\mathrm{Ne}=$ Number of effective alel, $\mathrm{I}=$ Shannon index, $\mathrm{h}=$ The genetic diversity; $\mathrm{uh}=$ Diversity is not biased and the percentage of polymorphic F0: $\mathrm{A}$ positive control is not irradiated and scanned with PEGF1: irradiated Planlet 25 gray gamma rays do not impact with PEGF2:irradiatedPlanlet 25 gray of gamma rays and induced with PEG 15\%F3: irradiated Planlet with gamma rays 25 gray and induced with PEG 30\%.

Table 3 shows a decrease of genetic diversity in the irradiated plantlets 25 gray of gamma rays that from 0231 into 0142 and 0178 padaF1 on the F2 and F3 0124. So also with the percentage of polymorphisms that occur $52 \%$ of the positive control decreased to $28 \%$ in treatment by PEG $30 \%$ it can be caused There is 
change gene's ability to withstand stress conditions PEG. Plants are able to survive the stress of PEG can be said to be resistant to high temperatures but very little resistance genes can be derived. Changes occur after treatment showed the changes of phylogenetic tree, into 2 main clusters irradiated and Top of Form.

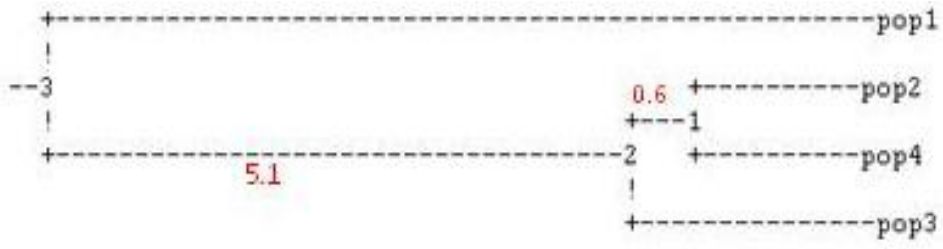

Fig. 2. Dendrogram population plantlets positive control treatment based on molecular character matrix inequality RAPD.

Based on Fig. 2, the use of PEG 30\% is not different clusters from no PEG, but show differences in class from a population irradiated after the analysis with Nei's Gene Diversity [11]. This could be due to somaclonal variation. Variation somaklonal happens in tissue culture is the cumulative result of a genetic mutation in the explants and induced the condition in vitro. Ref. [13] Variation somaklonal the genetic changes that are not caused by segregation or recombination of genes, as commonly occur due to the cross. This variability may arise due to the doubling of chromosome (fusion, endomitosis), changes in the number of chromosomes (tagging and nondisjunction), changes in chromosome structure, gene changes, and changes in the cytoplasm [14], [15].

In vitro selection is more efficient due to the condition of selection can be made homogeneous, relatively little space is required, and the effectiveness of the high selection. Therefore, the combination of the induction of somaclonal variation and selection in vitro is an alternative technology that is effective in producing individuals with specific characters [13]. The use of in vitro techniques will produce a population of cells through the selection of variants on the appropriate medium. Selection intensity can be strengthened and made more homogenous.Populasi tissue or plant cells can be selected in the selection media will increase the frequency variants with the desired properties [16], [17].

\section{Conclusion}

Gamma ray irradiation dose 25 gray works best for mutation induction chrysanthemum. Gamma rays as a mutagen in the induction of mutations has provided physical changes in chrysanthemum callus, the callus is still green. Chrysanthemum plantlets were simulated with Polyethylene Glycol to obtain varieties tolerant to temperatures in the plains of medium to demonstrate its ability to survive in the administration of PEG 15\%, plantlets look fresh, green leaves with life percentage reached 50.23\%. Using RAPD molecular test results also showed that irradiated plants 25 gray of gamma rays resistant to temperature stress in vitro.

\section{Acknowledgement}

Acknowledgements submitted to Ditlitabmas Kemenristek Higher Education, which has funded this research through Commodity Research Universities (PUPT). Also to LPPM UPN "Veteran" Yogyakarta that has facilitated this research activity can be settled.

\section{References}

[1] Wijayani, A., Muafi, W. E., \& Srilestari, R. (2015). Regeneration callus of chrysant after irradiated ray gamma for the resilience of plain medium. Journal Techno., 1, 61-67.

[2] Bappeda, D. I. Y. (2003). Regional Strategic Plan (Renstrada) DIY Province in 2004-2008. DIY Provincial 
Regulation No. 6 of 2003. The Regional Development Planning Board (Bappeda) Yogyakarta Province.

[3] Sirohi, P. S., \& Behera, T. K. (2000). Genetic variability in chrysanthemum. Journal of Ornamental Horticulture (New Series), 3, 134-136.

[4] Da, S. J. A. T. (2004). Ornamental chrysanthemums: Improvement by biotechnology. Journal of Plant Cell, Tissue and Organ Culture, 91-98.

[5] Sulistianingsih, R. (1999). The callus regeneration rice (oryza sativa) drought tolerant in vitro. Jurnal Azolla, 15, 139-150.

[6] Akhtar, M. S., Oki, Y., \& Nakashima, Y. (2015). Differential P-acquisition and growth characteristics of wheat cultivars under buffered P-stress environment. Journal of Bioscience, Biochemistry and Bioinformatics, 5, 311-320.

[7] Ashraf, J., Malik, W., Iqbal, M. Z., Khan, A. A., Qayyum, A., Noor, E., Abid, M. A., Cheema, H. M. N., \& Ahmad, M. Q. (2016). Comparatif analysis of genetic diversity among Bt cotton genotypes using EST-SSR, ISSR and morphological markers. J. Agr. Sci. Tech., 18, 517-531.

[8] Biswan, B., Chowdhurry, A. B., \& Mandal, B. (2002). In-vitro screening for increasing drought tolerance in rice. Vitro Cell Dev. Biol. Plant, 38, 525-530.

[9] Yiyao, L., Bochu, W., Xuefeng, L., Chuanren, D., \& Sakanishi, A. (2002). Effects of sound field on the growth of chrysanthemum callus. Colloids surfaces B: Biointerfaces, 24, 321-326.

[10] Yunita, R. (2009). Utilization of somaclonal variation and selection of in-vitro in assembly plants tolerant to abiotic stresses. J. of Agricultural Research, 28, 142-147.

[11] Annadana, S., Rademaker, W., Ramanna, M., Udayakumar, M., \& Jong, J. (2000). Response of stem explants to screening and explant sour as a basis for methodological advancing of regeneration protocols for chrysanthemum. Journal of Plant Cell, Tissue and Organ Culture, 62, 47-55.

[12] Serious, M. M. (2002). Phytoextraction of toxic metals: A review of biological mechanism. Journal of Environmental Qual., 31, 109-120.

[13] Jeong, J. H., Chakrabarty, D., Kim, S. J., \& Paek, K. Y. (2002). Transformation of chrysanthemum (dendrathema grandiflorum kitamura cv) cheonsu by constitutive expression of rice OsMADS1 gene. J. Kor. Soc. Hort. Sci., 43, 382-386.

[14] Fukai, S., Kamigaichi, Y., Yamasaki, N., Zhang, W., \& Goi, M. (2002). Distribution, morphological variations and cpDNA PCR-RFLP analysis of dendrathemayoshinagathum. Journal of Jap. Soc. Hort.Sci., $71,114-122$.

[15] Medina, F., Amano, E., \& Tano, S. (2004). Mutation breeding manual. FNCA (Forum for Nuclear Cooperation in Asia), 11-25, 84-87.

[16] Dwivedi, A. K., Banerji, B. K., Chakrabarty, D., Mandal A. K. A., \& Datta, S. K. (2000). Gamma ray induced new flower colour chimera and its management through tissue culture. Ind. J. Agric. Sci., 70, 853-855.

[17] Peakall, R., \& Smouse, P. E. (2008). Alex Gen 6: Genetic Analysis in Excel. Population Genetic Software for Teaching and Research. Australian ANTIONAL University, Canberra, Australia.

Ari Wijayani is a lecturer in the Department of Agronomy, Faculty of Agriculture UPN "Veteran" Yogyakarta since 1989. Ari Wijayani's extensive research related to ornamental plants. Ari Wijayani wrote many get grants, among others from BPPT-Research and Technology; Kemenristekdikti (research competitive grants, the National Strategic and Leading Universities); and LPDP-RISPRO MOF.

Ari Wijayani actives in professional associations, as general secretary of the Association of Agronomy Indonesia (fermenters) Komda DIY, members of the Association of Indonesian Orchid (PAI), chairman of the Center for the Study of Ornamental Plants in UPN Yogyakarta as well as chairman of Sentra HKI "WIMAYARISTEK" UPN Yogyakarta. 